\title{
RATIONALIZATION OF MANUFACTURING OF PLASTIC INJECTION MOULDS BY ABRASIVE WATERJET
}

\author{
Agáta Radvanská, Jana Petrů, Katarína Monková, Tomáš Zlámal, Pavol Hreha, \\ Matej Šomšák, Andrej Andrej, Branimir Šafran
}

Subject review

The article deals with a proposal and a theoretical solution for the rationalization of manufacturing of parts of plastic injection moulds by abrasive waterjet cutting. On the basis of experimental tests and by the application of advanced abrasive waterjet technology to the process of manufacturing of plastic injection moulds, it has been found that there is a possibility of considerable time saving, i.e. a marked shortage in time period from product ordering to dispatching. In such a way it is possible to increase the competitiveness of a company and to ensure its stable position on the market even in the time of global crisis.

Keywords: abrasive waterjet cutting; plastic injection mould

\section{Racionalizacija proizvodnje kalupa za ubrizgavanje plastike abrazivnim vodenim mlazom}

Rad se bavi prijedlogom i teorijskim rješenjem za racionalizaciju proizvodnje dijelova kalupa za ubrizgavanje plastike rezanjem abrazivnim vodenim mlazom. $\mathrm{Na}$ temelju eksperimentalnih ispitivanja i primjenom napredne tehnologije abrazivnog vodenog mlaza u procesu proizvodnje kalupa za ubrizgavanje plastike, utvrđeno je da postoji mogućnost prilične uštede vremena, odnosno značajno smanjenje vremena proteklog od narudžbe do isporuke proizvoda. Na taj je način moguće povećati konkurentnost tvrtke i osigurati joj stabilnu poziciju na tržištu, čak i u vrijeme globalne krize.

Ključne riječi: rezanje abrazivnim vodenim mlazom; kalup za ubrizgavanje plastike

\section{Introduction}

At present, the manufacturing of plastic mouldings having different shapes is no problem anymore; what is a problem is such manufacturing of them by the given company that this manufacturing is cost-effective [1]. It is completely evident that costs incurred during the manufacturing play a substantial role here. If unsuitable processes are used in the course of manufacturing, poor quality products are manufactured, or this manufacturing is ineffective, and thus manufacturing costs grow, which decreases a manufacturer's profit $[4,5]$. For this reason, it is unavoidable to find optimum conditions also for the costeffective manufacturing of high quality mouldings by means of plastic injection moulding technology. Each company that acts on the market under existing conditions has, with regard to a requirement for company survival and to a permanent pressure developed by competitors, to make efforts to keep increasing the cost-effectiveness of its own manufacturing $[7,8]$. Company processes are effective only if: 1) The costs that are inescapable in the course of manufacturing are minimized; 2) The level of technology is as required; 3) The high productivity of labour is ensured; 4) Production reacts altogether flexibly to customer needs.

\section{A state of the art analysis}

For the polymer injection moulding process, modern fully automated machines of high productivity are used [1]. An advantage of injection moulding is the use factor of material being treated that is close to $100 \%$. Injection moulding is a cyclic process. The technological process consists of two operations; plastic in a form of granules is fed into a hopper of the injection moulding machine from which it passes to a melting chamber that is heated by resistance bands; here the plastic is melted by heat. The molten plastic is injected and forced by the movement of a screw or injection ram into an injection mould cavity [6, 7, 9]. The plastic injection moulding machine is composed of an injection unit, in which polymers are melted and which supplies the polymer melt into the mould, and of a clamping unit, by means of which the mould is opened and closed for each injection cycle. The major parts of the machine are an injection system, a plastification system, a mould, a control system and a hydraulic system. The mould belongs to the parts of greatest importance to plastic injection moulding (Fig. 1).

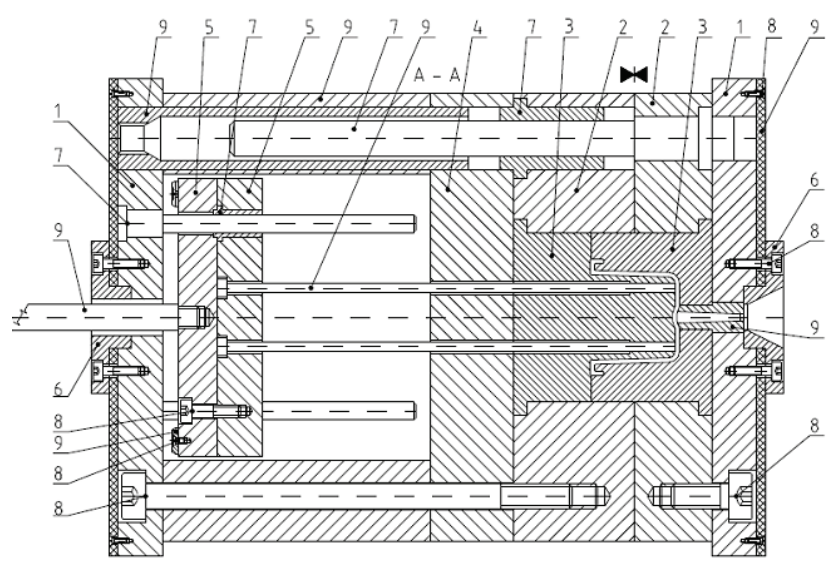

Figure 1 Diagram of an injection mould; 1 - clamp plates, 2 - anchor plates, 3 - shape elements, 4 - support plate, 5 - ejector plates, 6 separation rings, 7 - guide components, 8 - couplings, 9 - other components

The design and the manufacturing of an injection mould are usually performed by specialised companies tool works equipped as required for manufacturing. To prepare a high-quality mould design, close cooperation of a product designer and a mould designer is expected. From the constructional point of view, moulds have to withstand high pressures, have to provide products of accurate dimensions, have to enable the simple selection 
of products, and have to work automatically for its whole lifespan. The design and the manufacturing of moulds require much technical knowledge and are expensive. The selection of mould materials depends on the kind of plastic being treated, used technology, product size and product complexity, size of batch, heat resistance, wear resistance and corrosion resistance, price, and others. An important task in mould design is the determination of dimensions and manufacturing allowances of shape parts. The mould flask represents a group of interconnected plates with accessories for guiding and centring. From the functional point of view, it has to enable correct placement on the injection moulding machine, perfect and safe clamping on the machine, precise guiding of movable parts of the mould, simple mounting of shape elements and other functional components, suitable position of tempering and ejection systems; the size and the configuration of the flask are chosen individually as needed and according to the required function of the mould with regard to product moulding [1]. The shape and size accuracy and surface quality are given by the accuracy of shape cavity and the quality of its production. The moulding cavity, as inverse shape of the injection moulded piece, is formed in the shape elements, or directly in the mould flask, together with sprues. The shape, dimensions and surface of the cavity have to meet the requirements for the injection moulded piece. Individual variants of solution for the manufacturing process are based on technical data so that manufacturing may be successful. For the design of the injection mould, drawings and a model of the injection moulded piece and technical conditions provide basic data. The drawing of the injection moulded piece contains primarily ratio and direction allowances, special design requirements. The solution for the mould usually begins with the determination of its multiplicity. A significant factor in the selection of manufacturing process is the economic analysis in relation to the mould structural design. It is not only a case of economics of mould manufacturing, but it is also a case of overall economics of manufacturing. The initial cost of the mould is non-recurring, but the cost of manufacturing is permanently connected with the utilization of the mould. That is why the initial cost of the mould of complicated shape is often rather high. For this reason, the aim is just a decrease in initial cost in space and time of manufacturing of plastic injection moulds [7].

\section{Problem definition}

Plastic injection moulds manufactured by the company are divided by shape complexity and material. These materials rank among difficult-to-machine materials (Fig. 2). At using the existing method of manufacturing of the components of which the plastic injection mould consists, classical technological processes, such as drilling, milling, turning, grinding, core-drilling, and heat treatment are applied (Fig. 2) [14, $17,19,20,21]$. The production of a mould cavity of 200 $\times 150 \mathrm{~mm}$ size by milling into the depth of $46 \mathrm{~mm}$ takes 5 hours. The drilling of one hole $\varnothing 26$ to the depth of $46 \mathrm{~mm}$ takes 1 hour. There are minimally four transition holes in the mould so that the time required for the production of four holes is 4 hours. Waste produced by milling and drilling cannot be technologically used any more because it is in the form of metal chips contaminated with a cutting liquid (Fig. 3). In addition, handling such a kind of waste is difficult and storage is complicated, which represents another financial load of the company [14].

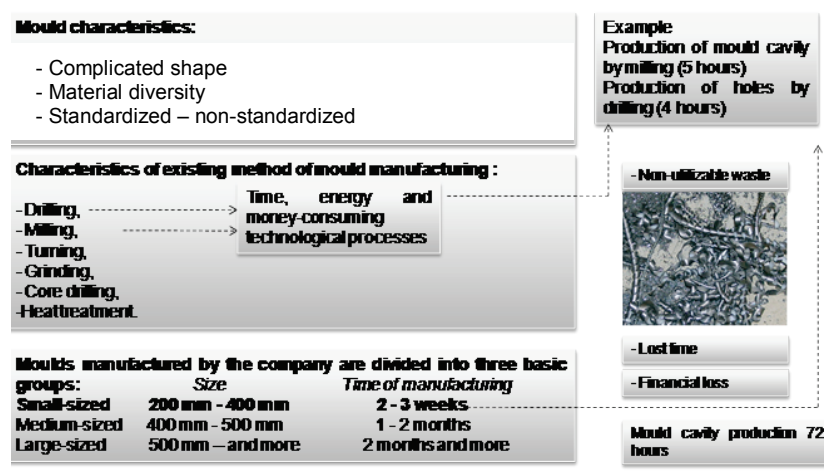

Figure 2 Diagram of existing methods of manufacturing of moulds

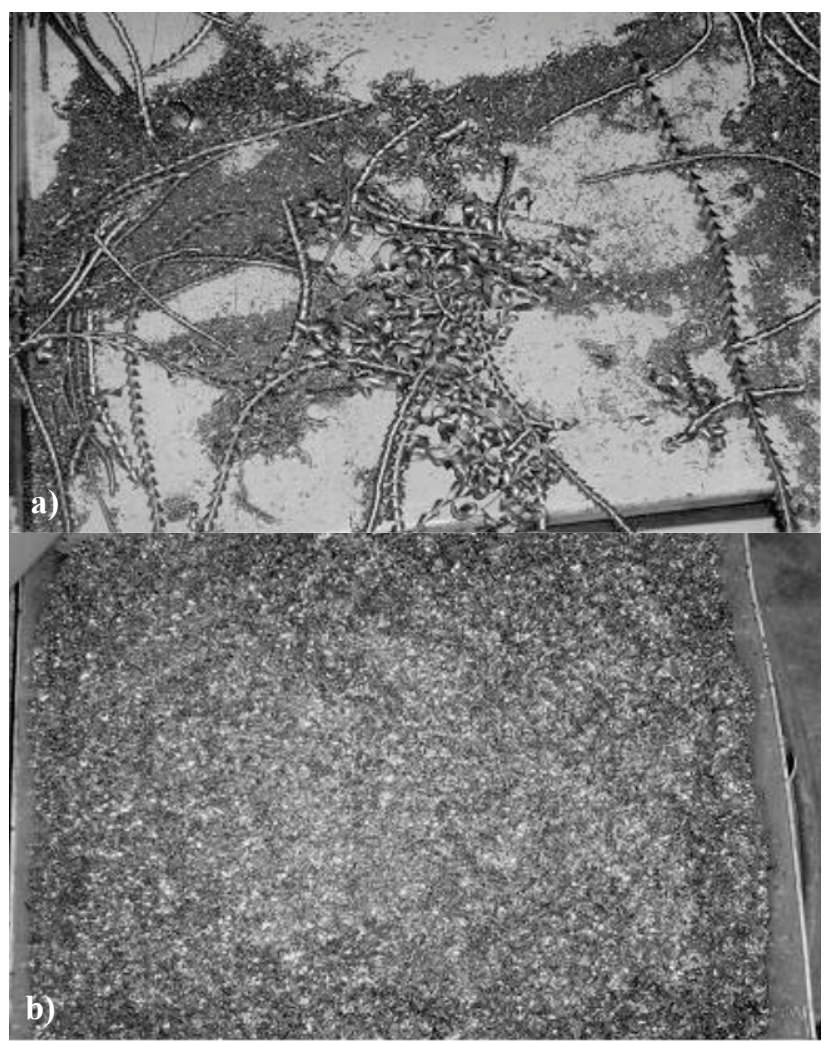

Figure 3 a) Iron and b) copper waste in the form of chips

It follows from the above-mentioned facts that the existing technological process of manufacturing of plastic injection moulds is time-consuming, expensive, and generates a lot of waste which cannot be used any more (Fig. 3)

\section{Proposal for manufacturing of mould parts by AWJ}

On the basis of the defined shortcomings, the main goal was the elimination of them by replacing the existing ways of manufacturing by abrasive waterjet cutting with expected reduction in cost and time for mould manufacturing with a possibility of utilization of waste generated. Reasons for AWJ application consist especially in versatility [3, 4] and well-known technological, ecological and economic benefits with a 
possibility of simple automation of this process $[2,10,11$, $12,15]$. Other significant reasons are the accuracy of a cut and little loss of material in the course of this cold process of cutting in comparison with other non-conventional thermal methods, during which a thermally affected zone is formed $[2,3,9,10]$. In the following figures there are construction drawings of an anchor plate (Fig. 4), ejector plate (Fig. 5), movable and stationary flasks (Fig. 6), and stationary and movable clamp plates (Fig. 7). In these figures, construction elements produced classically by drilling and milling are indicated by arrows.

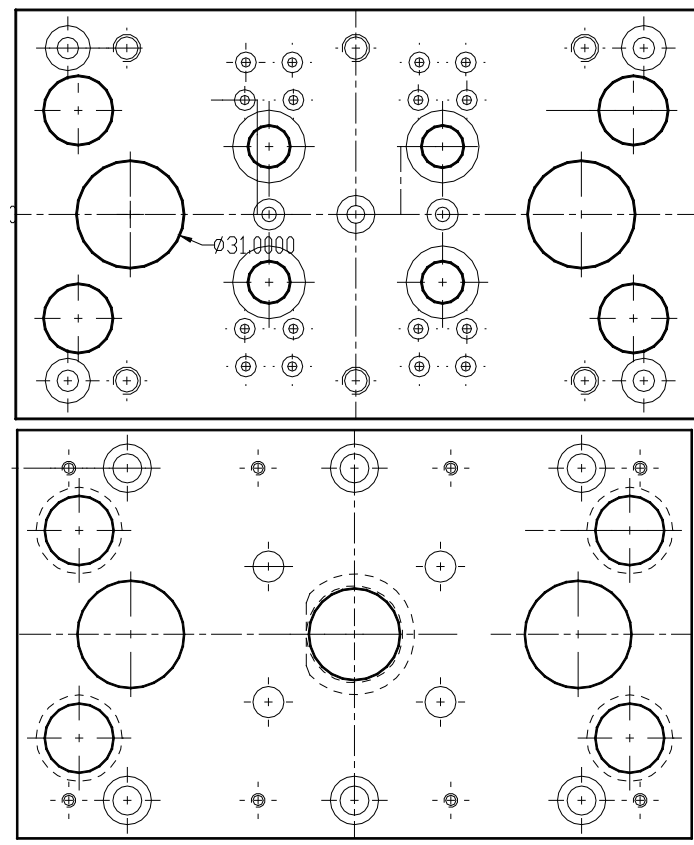

Figure 4 Anchor plate, material 11730 and ejector plate, material 11730

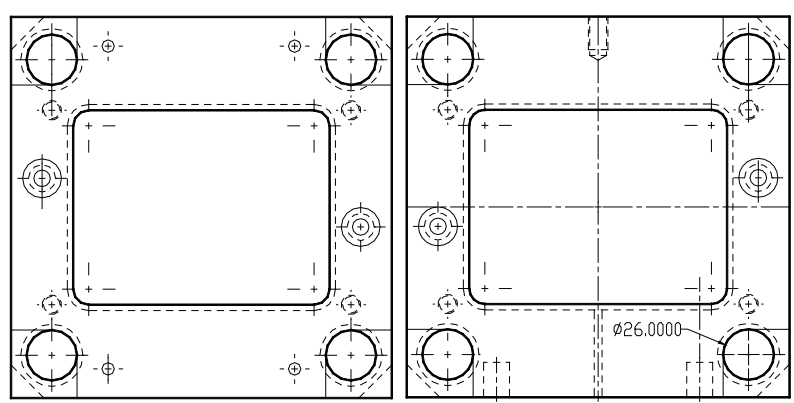

Figure 5 Movable flask and stationary flask, material 1.2312

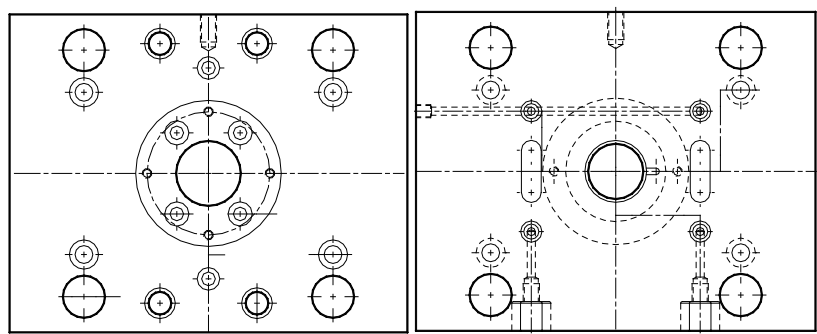

Figure 6 Movable clamp plate and stationary clamp plate, material 11730

In the course of performing experimental operations, it was found that the highest time saving was achieved during the manufacturing of the stationary and the movable mould flask. From the point of view of standardization, the fact whether the company manufactures moulds from sheets of material of standardized size or of non-standardized size is of importance. A sheet of non-standardized dimensions must be cut by the company to the required size which is to be further machined. For this operation, a sheet of material having standardized dimensions $250 \times 250 \mathrm{~mm}$ was used; the abrasive waterjet replaced fully milling and also drilling.

\section{Evaluation of rationalization of manufacturing}

One of the ways of rationalizing the manufacturing of parts for plastic injection moulds is the replacement of classical techniques by new ones. By a series of experimental tests, the cold method of materials cutting was applied to the production of holes in the anchor and ejector plates, of stationary and movable flasks and of movable and stationary clamp plates (Fig. 7).

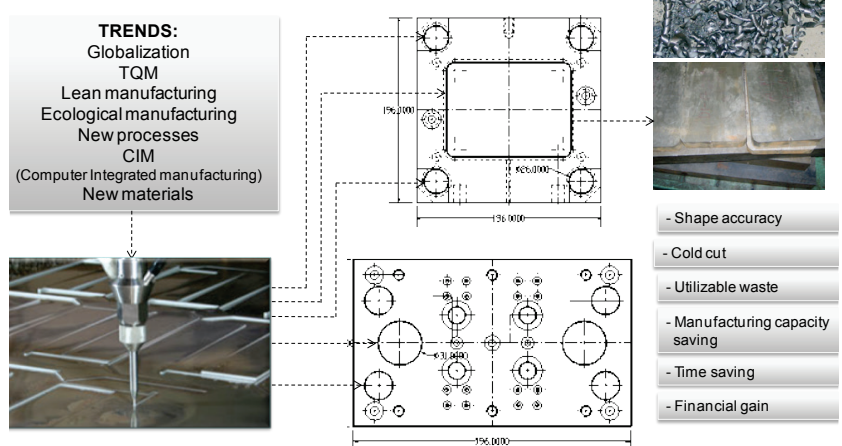

Figure 7 Advantages of abrasive waterjet technology application in the manufacturing of injection moulds

Experimentally, four holes of the diameter of $26 \mathrm{~mm}$ and a hole of $200 \times 150 \mathrm{~mm}$ size were cut using the AWJ technology. The time of production of the four holes was 10 minutes; the achieved time saving was 230 minutes, i.e. 3 hours and 50 minutes. The cutting of the hole of 200 $\times 150 \mathrm{~mm}$ size to the depth of $46 \mathrm{~mm}$ took 14 minutes, which represented the achieved time saving of 2 hours and 46 minutes. Waste generated by the application of abrasive waterjet cutting is compact, easy to handle, and what is of importance, it is utilizable for the potential manufacturing of rather small parts for moulds. The total time required for the manufacturing of the stationary and the movable flask of the plastic injection mould by abrasive waterjet manufacturing process was 6 hours and 48 minutes. In finishing operations, one shank end mill $\varnothing 12$ was used. As far as this manufacturing method is concerned, it is necessary to point out that the parts for injection moulds were test-manufactured using a small mould of $250 \times 250 \mathrm{~mm}$ size; the depth being $46 \mathrm{~mm}$.

The mill wore out in the course of milling, which caused costs of tool replacement. The stationary as well as the movable mould flask was milled and thus the loss was doubled. During the application of drilling technology, three pre-drill bits and one finishing drill were used. They wore minimally. For this manufacturing method, a larger number of workers were needed because it was necessary to transport moulds from the milling machine to the drilling machine. At the application of abrasive waterjet cutting of materials [16], the wear of tools was minimal, 
because milling was used merely for finishing the cut-out holes to the required dimensions. Additional material handling in the course of abrasive waterjet cutting is not necessary because the mentioned operations are performed on one machine and on one work bench. Generated waste is in the form of metal blocks and can be further used. The metal blocks are stored in the shop. The total amount of waste was reduced by more than half (Fig. 8).
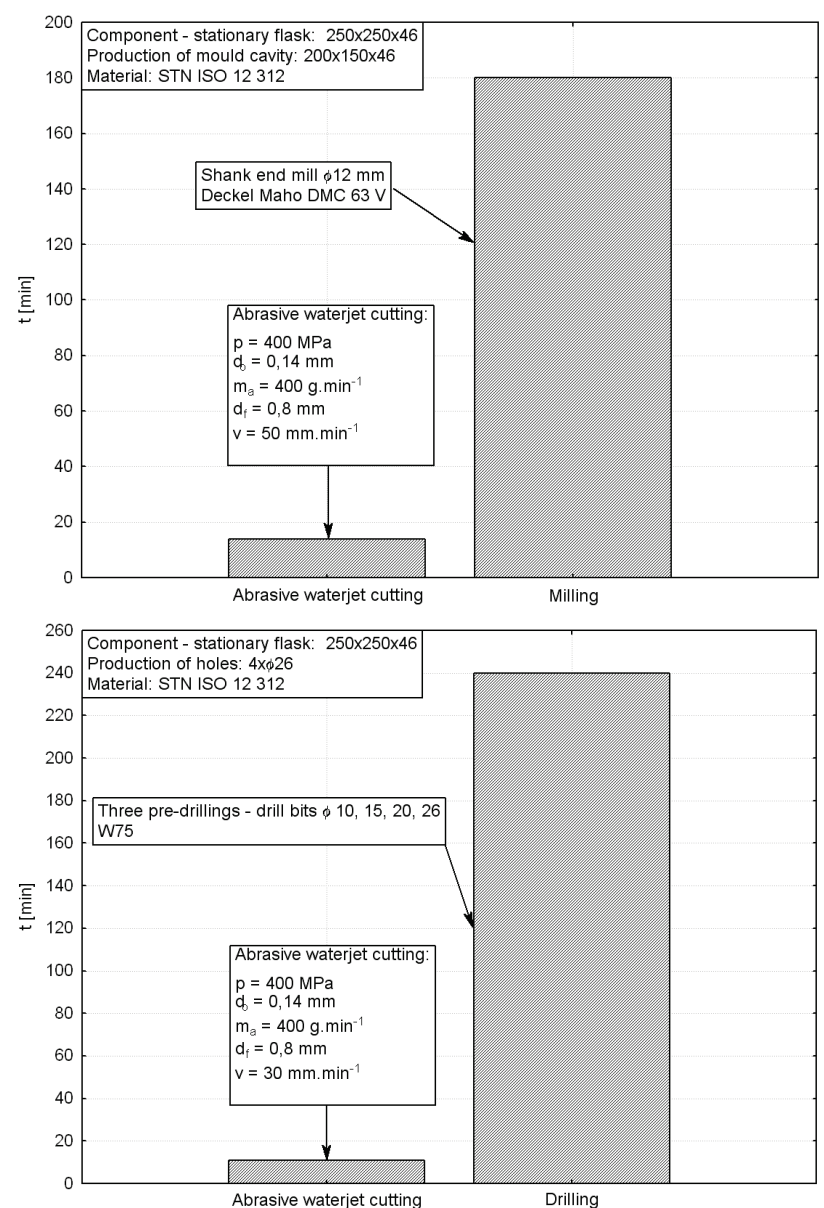

Figure 8 Examples of comparison of technologies for manufacturing of components

\section{Conclusion}

In the world there are a considerable number of companies concerned with the manufacturing of plastics. One of methods is the injection of plastics into moulds. Moulds are manufactured using the classical manufacturing method and the manufacturing of them is time and money consuming. In addition, there is a great demand for new moulds and companies are not able to satisfy all customers. At this manufacturing technique, it is quite difficult to satisfy all or at least more than half of customers, and one can say that it is even impossible. In dealing with the work described in the article participated the company $1^{\text {st }}$ Presov Tool Making Company, Ltd. in cooperation with the company DRC, Ltd.

By the application of abrasive waterjet cutting, the time of manufacturing of individual components is markedly shortened in comparison with the classical manufacturing method. This technology replaced, to a considerable extent, milling and drilling. Thanks to the abrasive waterjet cutting technology, disadvantages of classical manufacturing method were eliminated or at least reduced. Average cost of cutting material using abrasive water jet is 100 Euro per hour. The company will achieve the largest saving in time and money during the manufacturing of mould flask. The total time of manufacturing of the stationary and the movable flask of $250 \times 250 \mathrm{~mm}$ size of the plastic injection mould was 6 hours and 48 minutes. In comparison with the classical manufacturing method, the difference is 15 hours and 12 minutes. Using the abrasive waterjet jet cutting, the smaller number of workers participated in the whole process of manufacturing of the stationary and the movable mould flask and the wear of tools was minimal. Waste generated is in the form of metal blocks. The company further uses the generated waste. It is important to state that the work described in this article concerned the manufacturing of a small-sized mould. One can assume that in the case of medium and large-sized moulds, the saving in material and time will be greater. The company can use abrasive waterjet cutting mainly in the manufacturing of moulds having intricate shapes, where milling is much more difficult and complicated

\section{Acknowledgement}

Study was supported by project VEGA 1/0972/11 and by OP VK System of Education for Personnel Assurance of Research and Development in the Sphere of Modern Trend of Surface Engineering - Surface Integrity, reg. Project No. CZ.1.07/2.3.00/20.0037. This work was supported by the Slovak Research and Development Agency under the contract No. APVV-207-12.

\section{References}

[1] Greškovič, F.; Spišák, E. Mould materials for plastics processing. // Acta Metalurgica Slovaca. 9, 1(2003), pp. 4148.

[2] Sharma, V. et al. Multi response optimization of process parameters based on Taguchi-Fuzzy model for coal cutting by water jet technology. // International Journal of Advanced Manufacturing Technology. 56, 9-12(2011), pp. 1019-1025.

[3] Hreha, P.; Hloch, S.; Magurová, D. et al. Water jet technology used in medicine. // Tehnicki vjesnik-Technical Gazette. 17, 2(2010), pp. 237-240.

[4] Hloch, S. et al. Water jet technology using in orthopaedic surgery // Tehnicki vjesnik-Technical Gazette. 20, 2(2010), pp. 351-357.

[5] Lis, W.; Tabert, M. Modelling of business processes in enterprise. // In: CO-MAT-TECH 2000, $8^{\text {th }}$ International Scientific Conference, pp. 197- 203.

[6] Malega, P.; Engel, J. Achieving higher effectiveness through operational effectiveness. // In: Intercathedra No 22, Annual bulletin of plant - economy department of the European wood technology university studies, Poznań, (2006), pp. 96- 99.

[7] Menges, G.; Michaeli, W.; Mohren, P. How to make injection molds, Hanser publisher, Mníchov, 2001.

[8] Osswald, T.A.; Turng, T.; Gramann P.J. Injection molding handbook, Hanser publisher, München, 2001.

[9] Schmitz, J. Key Lessons In Manufacturing Effectiveness, The ISMI Symposium Future Fab Intl. Volume 18, Philips Research, 2005.

[10] Hreha, P.; Hloch, S. Potential use of vibration for metrology and detection of surface topography created by abrasive 
waterjet // Int. J. Surface Science and Engineering. 7, 2(2013), pp. 135-151. DOI: 10.1504/IJSURFSE.2013.053699

[11] Botak Z, Kondic Z, Maderic D. Waterjet Machining. // Tehnicki vjesnik-Technical Gazette. 16, (2009 (3), pp. 97 101.

[12] Hloch, S.; Ruggiero, A. Online Monitoring and Analysis of Hydroabrasive Cutting by Vibration. // Advances in Mechanical Engineering. Vol. 2013, ID 894561, (2013), pp. 10.

[13] Hreha, P. et al. Analysis of acoustic emission recorded during monitoring of abrasive waterjet cutting of stainless steel AISI 309. // Tehnicki vjesnik-Technical Gazette. 19, 2 (2012), pp. 355-359.

[14] Cuma, M.; Zajac, J. The impact analysis of cutting fluids aerosols on working environment and contamination of reservoirs. // Tehnicki vjesnik-Technical Gazette. 19, 2 (2012), pp. 443-446.

[15] Peržel, V. et al. Vibration emission as a potential source of information for abrasive waterjet quality process control. // International Journal of Advanced Manufacturing Technology. 61, 1-4(2012), pp. 258-294.

[16] Hloch, S. et al. Classification of technical materials according to classes machinability for hydroabrasive cutting. // Metalurgija. 51, 1(2012), pp. 125-128.

[17] Monka, P. The Comparison of Surface Roughness Characteristics Achieved by the Machining with Conventional and Unconventional Geometry of Tools. // Advanced Materials Research. 622-623(2012), p. 352-356, ISSN 1022-6680.

[18] Jakubeczyova, D.et al. Testing of thin PVD coats deposited on high speed steel PM // Chemical lists, 105, S(2011), p. 618-620, ISSN 0009-2770.

[19] Neslusan, M. et al. Deformation after heat treatment and their influence on cutting process. // Tehnicki vjesnik-Technical Gazette. 18, 4 (2011), pp. 601-608.

[20] Ragan, E. et al. Dynamic of taking out moulding parts at injection molding. // Metalurgija. 51, 4(2012), pp. 567-570

[21] Gaspar, S. et al. Dependence of pressure die casting quality on die casting plunger velocity inside a filling chamber of a pressure die casting machine. // Advanced Science Letters. 14, 1(2012), pp. 499-502. DOI: 10.1166/asl.2012.3989

\section{Authors' addresses}

Agáta Radvanská
Katarína Monková
Pavol Hreha
Matej Šomšák
Andrej Andrej
Faculty of Manufacturing Technologies
of Technical University of Košice with a seat in Prešov
Bayerova 108001 Prešov, Slovak Republic

\section{Jana Petrů}

Tomáš Zlámal

Faculty of Mechanical Engineering,

VŠB - Technical University of Ostrava,

70833 Ostrava-Poruba, Czech Republic

Branimir Šafran, mag. ing. techn. lign.

University of Zagreb, Faculty of Forestry,

Dept. of Processes Engineering

Svetošimunska 25, 10002 Zagreb, Croatia 